\title{
Experimental Application of a Laboratory SBR Plant Used for Domestic Wastewater Treatment
}

\author{
NARCIS BARSAN ${ }^{1}$, DANA CHITIMUS ${ }^{1 *}$, FLORIN MARIAN NEDEFF ${ }^{1 *}$, ION SANDU2,3, MIRELA PANAINTE LEHADUS ${ }^{1}$, \\ ANDREI VICTOR SANDU ${ }^{3,4}$, OANA IRIMIA TARTOACA ${ }^{1}$ \\ ${ }^{1}$ Vasile Alecsandri University of Bacau, 157, Calea Marasesti Str., 600115 Bacau, Romania \\ ${ }^{2}$ Alexandru Ioan Cuza University of lasi, Arheoinvest Interdisciplinary Platform, Scientific Investigation Laboratory, 11 Carol I \\ Blvd., 700506 lasi, Romania \\ ${ }^{3}$ Romanian Inventors Forum, 3 Sf. Petru Movila St., Bloc L11, III/3, 700089, Iasi, Romania \\ ${ }^{4}$ Gheorghe Asachi Technical University of Iasi, Materials Science and Engineering Faculty, 53A D. Mangeron Blvd., 700050, Iasi, \\ Romania
}

\begin{abstract}
This paper presents a research regarding the possibility of small an SBR plant utilization in real condition of low flow wastewater. Were used domestic wastewater and the experimental period of 60 days was divided in three period. Seven chemical and physical wastewater quality parameters were evaluated during each working period of the installation and we also tried to highlight some correlations between the specific time cycle for an SBR and the reduction of wastewater quality parameters. The data obtained reveal that the low SBR plant efficiency is influenced by the input flow and their characteristics. Were obtain in some cases more that $60 \%$ reduction for three wastewater quality parameters.
\end{abstract}

Keywords: wastewater, SBR, quality indicators

The water problems management is an actual issue all over the world. The developed countries involve modern strategies to perform the water and wastewater infrastructures management. The good practice strategies applied in the west of EU countries can offer some models for east European countries where the water and wastewater managementstill present some real problems if we consider the real investments and the how the actual infrastructure perform.

The problems of water and wastewater management in Romania, as a part of east European countries with real issue in these sector, can be divided in two major direction: new investments (considering the European strategies and founds) and national performance strategies (by introducing the regional and national monitoring plans to obtain maximum performance for the actual infrastructure and human resources involved).

Romania has, in recent years, some good results in wastewater infrastructure management if we refer to localities with more than 10,000 equivalent inhabitants. The real problems remain in small localities and in the rural areas were exist some particularities regarding the demographic evolution water resources and social aspects [1-14].

To resolve the wastewater problems in the small localities the SBR (Sequencing Batch Reactor) plant can be taken into consideration.

Unlike conventional mechanical-biological systems, where the treatment process (aerobic and/or anaerobic) is divided into several tanks, in the case of an SBR plants the treatment is divided by operation times. Thus, the SBR wastewater treatment systems can be an alternative to the conventional wastewater treatment systems with the variables for inlet. This method, unlike continuous treatment systems, can be easier adapted to inlet concentration variation [15-22].

In an SBR wastewater treatment installation, the treatment takes place under automatic control, the biological reactor being the main element of the system.
The SBR systems treatment process is divided by using a single basin, with sequential operation times. A complete cycle is filling, reaction (aerobic/anaerobic), settling and treated wastewater evacuation. One of the most important advantages of SBR systems include the possibility of operating cycle time modify [15-22].

This paper aims to identify the possibility of a real operation condition (by using domestic wastewater) for a small SBR treatment system, by evaluation of some physical and chemical wastewater parameters.

\section{Experimental part}

Materials and methods

The research was oriented to the use of a small Sequencing Batch Reactor (SBR) treatment system utilized in a real working condition for domestic wastewater treatment. In these sense, real wastewater from Vasile Alecsandri Universisty of Bacau campus were used. For a proper SBR installation work, we use a septic tank as pretreatment method [18].

To avoid the process perturbation the installation was placed in a controlled closed location and the wastewater were pumped in the septic tank by simulating a real condition use for $a$ to 7 equivalent inhabitants (figure 1). The volume of the wastewater treated in the experimental installation was kept constant during the experiment at a level of $0.27 \mathrm{~m}^{3} /$ operating cycle. Taking into account the five operation phases of an SBR system, an operating cycle of the experimental installation consists of: SBR compartment filling without wastewater mixer; The reaction phase, with aerobic and anaerobic conditions; The settling; Treated wastewater evacuation, the treated water is evacuated from the top of the basin without the active sludge from the bottom [18].

A specific operation time of the plantrefers to the sludge recirculation phase, in the septic compartment, thatoccurs after each cycle. This sludge recirculation ensures inoculation for septic tank to accelerate the biological processes. The operation times for SBR cycle are presented

\footnotetext{
* email: dana.chitimus@ub.ro; florin_nedeff@ub.ro
} 


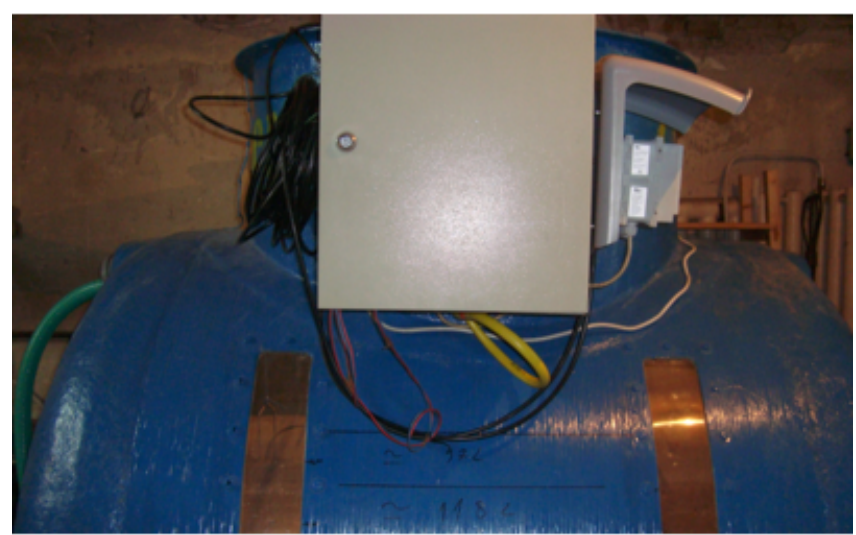

Fig. 1. SBR Plant

in Table 1. To evaluate cycle times in the SBR in some wastewater parameter reduction, the experimental period of 60 days, was divided into three stages (table 1) [18].

The wastewater monitored parameters were temperature: $\mathrm{pH}$, total solid suspension, $\mathrm{BOD}_{5}, \mathrm{COD}$, ammonium nitrogen and total phosphorus. To perform these parameters measurements were used the equipment's: OxiTop (respirometric method to measure the $\mathrm{BOD}_{5}$ ) (figure $2 \mathrm{a}$ ), inoLab Multi Level 1 (for $\mathrm{pH}$ ) (figure 2 b) and Odyssey DR/2500 (COD, ammonium nitrogen and total phosphorus (TP) determination) (figure 2c) [18].

\section{Results and discussions}

Considering the operation key parameters and process, the SBR plant were inoculated two weeks before experiment. At the end of each experimental period $(20$ days) the wastewater parameter was determined both for inlet and effluent. The parameters values variation are presented in figures 3 and 4 [18, 23, 24].

From the below figures it is observed that the wastewater used in the experimental study (inlet) is under NTPA 002 limit values for four quality indicators. Even though, the values presented in the graph show that the wastewater used in the study present qualitative variations over time. Also, the effluent parameters (TSS, $\mathrm{BOD}_{5}$ and $\mathrm{NH}_{4}^{+}$) values are over NTPA 001 limit in all cases.

The inlet parameter values (figure 3 ) were specific for a domestic wastewater, but for a low flow, we can consider that, the measured values, are difficult to treat in small plants. Even if in the third experimental period we obtain the lower concentration for all parameter of the effluent, the excess of the NTPA 001 limits can be a result of the plant operation performances for the wastewater type. Operation times cycle modification reveal that it is very important to establish some optimum conditions in the process in special in the cases of low flow treatment.

From the table 2 it is observed that $\mathrm{pH}$ value is according with NTPA 001 and 002 limits and the wastewater

\begin{tabular}{|c|c|c|c|}
\hline Times cycle & $\begin{array}{c}\text { First } \\
\text { interval }\end{array}$ & Second interval & Third interval \\
\hline tfiling & $572 \mathrm{~s}$ & $572 \mathrm{~s}$ & $572 \mathrm{~s}$ \\
\hline$t_{\text {denenitrification }}$ & $360 \mathrm{~s}$ & $300 \mathrm{~s}$ & $240 \mathrm{~s}$ \\
\hline tritrification & $240 \mathrm{~s}$ & $300 \mathrm{~s}$ & $360 \mathrm{~s}$ \\
\hline tsludger recirculation & $5 \mathrm{~s}$ & $10 \mathrm{~s}$ & $15 \mathrm{~s}$ \\
\hline$t_{\text {total cal cycle }}$ & $25749 \mathrm{~s}$ & $25754 \mathrm{~s}$ & $25759 \mathrm{~s}$ \\
\hline
\end{tabular}

Table 1

TIMES CYCLE OPERATIONS FOR THE EXPERIMENTAL PERIOD

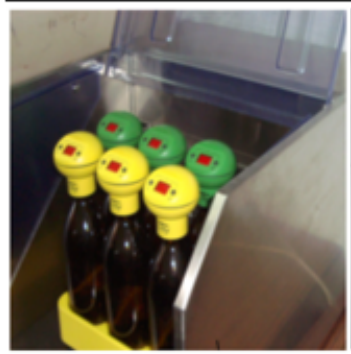

a

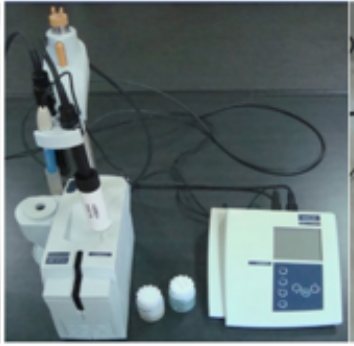

b

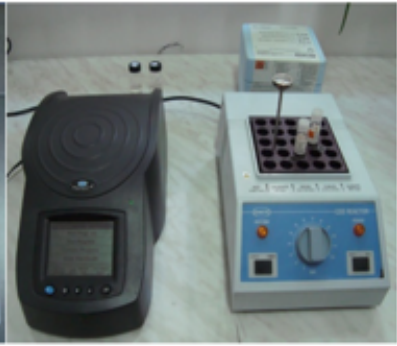

c
Fig. 2. Laboratory used equipment's [18]: a OxiTop, b inoLab Multi Level 1 and c Odyssey $\mathrm{DR} / 2500$

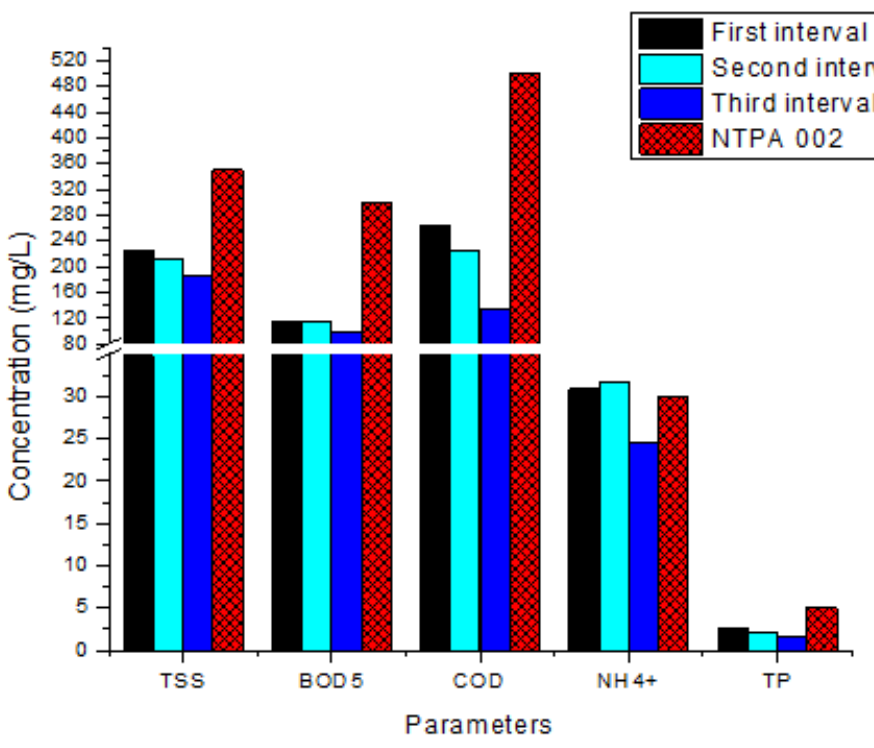

temperature present some lower values. The inlet lower temperature can affect the SBR plant operation process even if the sept tank resolves the equalization flow variation. The biological processes are directly influenced by wastewater temperature in special for low flow treatment. (\%).

The Figure 5 present the analyzed parameters reduction

From the below graph can be observed that the reduction is relatively in the same range for all wastewater quality indicators. The most visible increase is observed in the case of the first and the second experimental period when we obtain differences especially in the case of $\mathrm{BOD}_{5}, \mathrm{COD}$ and $\mathrm{NH}_{4}^{+}$. Also, the data presented in the graph show that in the first subperiod, were obtained 48 to $50 \%$ reduction were obtained for four all analyzed indicators. In the second

Fig. 3. Concentration values variation for the inlet parameters 


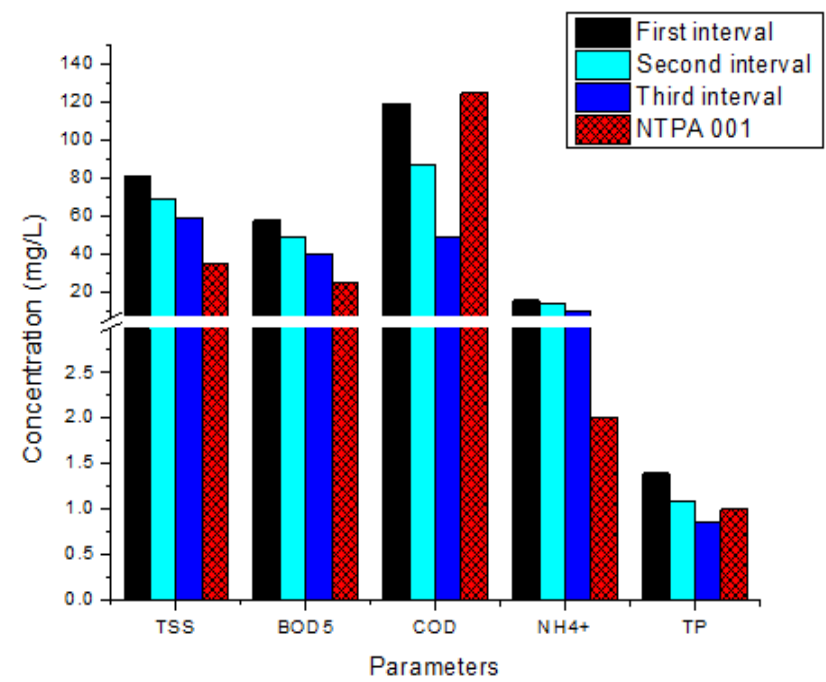

Fig. 4. Concentration values variation for effluent parameters

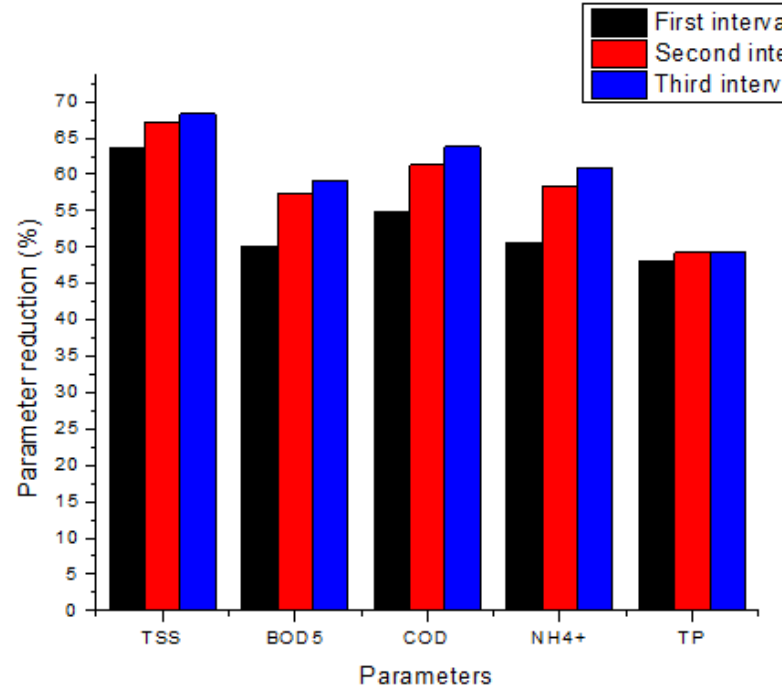

Fig. 5. Parameters reduction (\%)

Table 2

WASTEWATER TEMPERATURE AND PH VALUES

\begin{tabular}{|c|c|c|c|c|c|c|c|c|}
\hline Parameter & \multicolumn{4}{|c|}{$\begin{array}{c}\text { Temperature } \\
{ }^{\circ} \mathrm{C}\end{array}$} & \multicolumn{4}{|c|}{$\begin{array}{c}\mathrm{pH} \\
\text { unit. } \mathrm{pH}\end{array}$} \\
\hline $\begin{array}{l}\text { Samples/ } \\
\text { reference }\end{array}$ & $\begin{array}{l}\text { Inlet } \\
\text { value }\end{array}$ & $\begin{array}{c}\text { NTPA } 002 \\
\text { limit }\end{array}$ & $\begin{array}{l}\text { Effluent } \\
\text { value }\end{array}$ & $\begin{array}{c}\text { NTPA } 001 \\
\text { limit }\end{array}$ & $\begin{array}{l}\text { Inlet } \\
\text { value }\end{array}$ & $\begin{array}{c}\text { NTPA } \\
002 \\
\text { limit }\end{array}$ & $\begin{array}{c}\text { Effluent } \\
\text { value }\end{array}$ & $\begin{array}{c}\text { NTPA } \\
001 \\
\text { limit }\end{array}$ \\
\hline $\begin{array}{l}\text { Second } \\
\text { interval }\end{array}$ & 12.5 & 40 & 19.5 & 35 & 6.8 & $6.5-8.5$ & 7.2 & $6.5-8.5$ \\
\hline Third interval & 16.1 & & 20.5 & & 7.1 & & 7.4 & \\
\hline
\end{tabular}

period, reduction over $60 \%$ were obtained for two quality indicators analyzed. In all three experimental period it is observed that the lowest reduction was obtained for phosphorus, below 50\%.

\section{Conclusions}

The SBR plant and experimental procedures proved some real possibilities to treat low flow domestic wastewater in real conditions.

Even if the SBR plant are adaptive at flow variation we obtain relative low reduction for evaluated wastewater quality analyzer parameter. This aspect can be a consequence of the inoculation period (was used only insitu inoculation) and of the low wastewater temperature (with a very important role in pre-treatment and biological processes).

Continuous monitoring of the SBR operation cycle times and how the physical and biochemical processes can be influenced, creates the possibility of identifying methods to reduce plant working time and to increase wastewater parameter reduction.

\section{References}

1.FABIAN, F., NEDEFF, V., BIRSAN, N., MOSNEGUTU, E., Energy and Chemicals Consumption Evaluation in Water Treatment Plant $A$ comparative study between Bacau and Turin, Rev.Chim. (Bucharest), 70, no. 3, 2019, p. 881-886.

2.IRIMIA, O., TOMOZEI, C., PANAINTE, M., MOSNEGUTU, E.F., BARSAN, $\mathrm{N}$., Efficiency of filters with different filtering materials: comparative study in water treatment, Environmental Engineering and Management Journal, 12, no. 1, 2013, p. 35-39.
3.TIRTOACA IRIMIA, O., NEDEFF, V., PANAINTE-LEHADUS, M., TOMOZEI, C. Efficiency of water filtering process depending on the filter layer porosity and flow-a mathematical model, Journal of Engineering Studies and Research, 22, no. 4, p. 54-61.

4.TATARU, L., NEDEFF, V., BARSAN, N., MOSNEGUTU, E., PANAINTELEHADUS, M., SANDU, I., CHITIMUS, D., Studies of Humic Acid Removal from Aqueous Systems by Using Polymeric Membrane Ultrafiltration Process, Mat. Plast. 55, no. 4, 2018, p. 660-685.

5.TATARU, L., NEDEFF, V., BARSAN, N., SANDU, A.V., MOSNEGUTU, E., PANAINTE-LEHADUS, M., SANDU, I., Applications of Polymeric Membranes Ultrafiltration Process on the Retention of Bentonite Suspension, Mat. Plast. 56, no. 1, 2019, p. 97-102.

6.MISAILA, L., NEDEFF, F. M., BARSAN, N., SANDU, I.G., GROSU, L., PATRICIU, O.I., GAVRILA, L., FINARU, A.L., WATERSHED - android application for the mineral waters, classification, Rev.Chim. (Bucharest), 70, no. 6, 2019, p. 2212-2217.

7.EBLIN, S.G., KONAN, K.S., MANGOUA, O.M.J., NEDEFF, V., SANDU, A.V., BARSAN, N., SANDU, I., Nitrate Pollution of Groundwater Based on GIS in the City of Daloa, West-central Cote d'Ivoire, Rev.Chim. (Bucharest), 70, no. 7, 2019, p. 2579-2583.

8.COCHIORCA, A., NEDEFF, V., BARSAN, N., MOSNEGUTU, E.F, PANAINTE-LEHADUS M., Aspects related to water quality assessment in a mining activity area. Case study, mining area Targu Ogna, Romania. International Multidisciplinary Scientific GeoConference: SGEM: Surveying Geology \& Mining Ecology Management, 18, 2018, p. 87-94. 9.COCHIORCA, A., NEDEFF, V., BARSAN, N., PANAINTE-LEHADUS, M., MOSNEGUTU, E.F., Aspects related to water quality assessment in a mining activity area. Case study, mining area Tg. Ogna, Romania, Proceeding of the International Multidisciplinary Scientific Geo Conference Surveying Geology and Mining Ecology Management, SGEM, 18, no. 3.1., 2018, p. 87-94.

10.RADU, V.M., IONESCU, P., DEAK, G.Y., Journal of Environmental Protection and Ecology, 16, no. 2, 2015, p. 610. 
11.ILIE, M., GHITA, G., MATEI, M., DEAK, G.Y., DUMITRU, D.F., MONCEA, A.M., MARINESCU, F., LASLO, L.A., FRONESCU, D.F., DAESCU, V., Journal of Environmental Protection and Ecology, 19, no. 2, 2018, p. 646.

12.DAESCU, A.I., HOLBAN, E., BOBOC, M.G., RAISCHI, M.C., MATEI, M., ILIE, M., DEAK, G., DAESCU, V., J ournal of Environmental Protection and Ecology, 18, no. 1, 2017, p. 304.

13.HOLBAN, E., DEAK, G.Y., DAESCU, V., DIACU, E., DAESCU, A.I., TANASE, G.S., MARINESCU, P., SIRBU, C., PACEAGIU, J., Journal of Environmental Protection and Ecology, 16, no. 2, 2015, p. 479.

14.IONESCU, P., DEAK, G., DIACU, E., RADU, V.M., Rev. Chim (Bucharest), 67, no. 11, 2016, p. 2148.

15.BARSAN, N., J OITA, I., STANILA, M., RADU, C., DASCALU M., Modelling wastewater treatment process in a small plant using a Sequencing Batch Reactor (SBR), Environmental Engineering and Management Journal, 13, no. 7, 2014, p. 1561-1566.

16.BARSAN, N., NEDEFF, V., TEMEA, A., MOSNEGUTU, E., CHITIMUS A.D., TOMOZEI, C., A perspective for poor wastewater infrastructure regions: a small-scale Sequencing Batch Reactor treatment system, Chemistry journal of Moldova, 12, no. 1, 2017. p. 61-66.

17.BARSAN, N., NEDEFF, V., MOSNEGUTU, E.F., PANAINTE, M., Heat balance components of a small sequencing batch reactor applied for municipal wastewater treatment, Environmental Engineering and Management J ournal, 11, no.12, 2012, p. 2131-2138.
18.BARSAN, N., Studies and research for increase treatment capacity of municipal wastewater in small plants, PhD Thesis, Vasile Alecsandri University of Bacau, 2011.

19.BUNGAY, S., HUMPHRIES, M., STEPHENSON, T., Operating strategies for variable flow sequencing batch reactors, Journal of Water and Environment, 21, 2007, p. 1-8.

20.MAHVI, A.H., Sequencing batch reactor, a promising technology in wastewater treatment, Journal of Environmental Health Science and Engineering, 5, 2008, p. 79-90.

21.MESDAGHINIA, A.R., MAHVI, A.H., KARAKANI, F., Feasibility of continuous flow sequencing batch reactor in domestic wastewater treatment, American J ournal of Applied Sciences, 1, 2004, p. 348-353. 22.FREITAS, F., TEMUDO, M.F., CARVALHO, G., OEHMEN, A., REIS, M., Robustness of sludge enriched with short SBR cycles for biological nutrient removal, Journal of Bioresource Technology, 100, 2009, p. 1969-1976.

23.***Romanian Standard of wastewater disposal in natural effluent (NTPA) 001, 2005. In concordance with implementation of Council Directive of 21 May 1991, concerning urban wastewater treatment (91/ 271/EEC) (in Romanian).

$24 . * *$ Romanian Standard of wastew ater disposal in sewage network or in wastewater treatment plant (NTPA) 002, 2005. In concordance with implementation of Council Directive of 21 May 1991, concerning urban wastewater treatment (91/271/EEC) (in Romanian)

$\overline{\text { Manuscript recveived: } 12.11 .2019}$ 